Acknowledgments. We appreciate of Dr F. Tabesh and Dr M. Mirbod due to their helpful comments.

Financial support. No financial support was provided relevant to this article.

Conflicts of interest. All authors report no conflicts of interest relevant to this article.

\section{References}

1. Xu H, Zhong L, Deng J, Peng J, Dan H, Zeng X, et al. High expression of ACE2 receptor of 2019-nCoV on the epithelial cells of oral mucosa. Int $J$ Oral Sci 2020;12:8.

2. Wevers BA, Hoek L van der. Renin-angiotensin system in human coronavirus pathogenesis. Future Virol 2010;5:145-161.

3. Clarke NE, Turner AJ. Angiotensin-converting enzyme 2: the first decade. Int J Hyperten 2012; Article ID 307315. doi: 10.1155/2012/307315.

4. Abdul-Hafez A, Mohamed T, Omar H, Shemis M, Uhal BD. The renin angiotensin system in liver and lung: impact and therapeutic potential in organ fibrosis. J Lung Pulm Respir Res 2018;5(1). pii: 00160.

5. Chappell MC, Al Zayadneh EM. Angiotensin-(1-7) and the regulation of antifibrotic signaling pathways. J Cell Signal 2017;2(1):134.

6. Yang $\mathrm{P}, \mathrm{Gu} \mathrm{H}$, Zhao Z, et al. Angiotensin-converting enzyme 2 (ACE2) mediates influenza H7N9 virus-induced acute lung injury. Sci Rep 2014;4:1-6.

7. Bernheim A, Mei X, Huang M, et al. Chest CT findings in coronavirus disease-19 (COVID-19): relationship to duration of infection. Radiology 2020;200463. doi: 10.1148/radiol.2020200463.
8. Single-cell RNA expression profiling of ACE2, the putative receptor of Wuhan 2019-nCov. bioRxiv website. https://www.biorxiv.org/content/10. 1101/2020.01.26.919985v1.full. Published January 26, 2020. Accessed February 27, 2020.

9. Cheetham C, Collis J, O'Driscoll G, Stanton K, Taylor R, Green D. Losartan, an angiotensin type 1 receptor antagonist, improves endothelial function in non-insulin-dependent diabetes. J Am Coll Cardiol 2000;36:1461-1466.

10. Ranjbar H, Aghaei I, Moosazadeh M, Shabani M. Angiotensin II type 1 receptor blocker losartan attenuates locomotor, anxiety-like behavior, and passive avoidance learning deficits in a subchronic stress model. Iran J Basic Med Sci 2018;21:856-862.

11. Salama ZA, Sadek A, Abdelhady AM, Darweesh SK, Morsy SA, Esmat G. Losartan may inhibit the progression of liver fibrosis in chronic HCV patients. Hepatobil Surg Nutr 2016;5:249-255.

12. Choi JA, Kim J-E, Ju H, et al. The effects of losartan on cytomegalovirus infection in human trabecular meshwork cells. PLoS One 2019;14(6): e0218471.

13. Sellers SL, Milad N, Chan R, et al. Inhibition of Marfan syndrome aortic root dilation by losartan: role of angiotensin ii receptor type 1-independent activation of endothelial function. Am J Pathol 2018;188: 574-585.

14. Guo F, Sun YB, Su L, et al. Losartan attenuates paraquat-induced pulmonary fibrosis in rats. Hum Exp Toxicol 2015;34:497-505.

\title{
SARS-CoV-2 enterocolitis with persisting to excrete the virus for approximately two weeks after recovering from diarrhea: A case report
}

\author{
Tomohiro Hosoda MD, $\mathrm{PhD}^{1}$, Mitsuo Sakamoto MD, $\mathrm{PhD}^{1}$, Hideaki Shimizu² and Nobuhiko Okabe MD, PhD ${ }^{2}$ \\ ${ }^{1}$ Department of Infectious Disease, Kawasaki Municipal Kawasaki Hospital and ${ }^{2}$ Kawasaki City Institute for Public Health
}

To the Editor-In December 2019, a novel corona virus (SARS-CoV-2) was first isolated from patients in Wuhan, China. Since then, the outbreak has rapidly evolved mainly in Wuhan and Hubei Province and outside China. ${ }^{1}$ The outbreak on a large cruise ship docked in Yokohama, south of Tokyo, in January 2020 was the largest outbreak outside China. Person-to-person transmission of the virus has led to an epidemic of coronavirus disease 2019 (COVID-19). Throat swabs are used for screening or diagnostic purposes to identify individuals infected with this virus or possible carriers. Reverse transcriptase-polymerase chain reaction (RT-PCR) tests may have lower sensitivity when throat swabs are used than with nasal swab samples. ${ }^{2}$

An 81-year-old Japanese woman presented with a $\sim 6$-day history of abdominal pain, watery diarrhea, and a mild sore throat. However, she denied any fever and respiratory symptoms. She was transferred to our hospital from the aforementioned cruise ship

Author for correspondence: Tomohiro Hosoda, E-mail: ottotto723@gmail.com

Cite this article: Hosoda T, et al. (2020). SARS-CoV-2 enterocolitis with persisting to excrete the virus for approximately two weeks after recovering from diarrhea: A case report. Infection Control \& Hospital Epidemiology, 41: 753-754, https://doi.org/10.1017/ ice. 2020.87 (the site of the largest outbreak of SARS-CoV-2 in Japan) for evaluation and treatment of her abdominal symptoms. Her past medical history was unremarkable other than total gastrectomy for gastric cancer 5 years prior to presentation. Abdominal computed tomography on admission revealed acute enterocolitis without ileus or pneumonia. RT-PCR tests performed on throat swabs obtained at the time of transfer from the cruise and on day 4 of hospitalization showed negative results for SARS-CoV-2. However, RT-PCR testing of a stool sample obtained on day 2 of hospitalization showed positive results (2,000 copies per well), and she was diagnosed with acute enterocolitis secondary to COVID-19. Healthcare workers at our hospital performed contact and droplet precautions as essential components of patient care. She recovered from the diarrhea on day 4of hospitalization; however, RT-PCR testing of the stool sample continued to be positive on day 15 of hospitalization (200 copies per well). Negative results of the stool samples were obtained on days 16 and 17 of hospitalization.

Some patients in Wuhan, China, presented with diarrhea prior to the onset of fever and dyspnea. ${ }^{3}$ SARS-CoV-2 may be isolated from a diarrheal stool sample, which could cause person-to-person transmission. ${ }^{4}$ In our patient, the lack of gastric acid (attributable to the patient's history of total gastrectomy) could have resulted 
in the detection of SARS-CoV-2 in her stool sample. Clinicians should be mindful of the fact that COVID-19 may manifest as enterocolitis in patients without respiratory tract infection, and they should provide thorough instruction in hand hygiene because patients, even after recovering from enterocolitis due to COVID-19, could continue to excrete the virus for weeks.

Acknowledgments. None.

Financial support. No financial support was provided relevant to this article. Conflicts of interest. All authors report no conflicts of interest relevant to this article.

\section{References}

1. Chen $\mathrm{N}$, Zhou M, Dong X, et al. Epidemiological and clinical characteristics of 99 cases of 2019 novel coronavirus pneumonia in Wuhan, China: a descriptive study. Lancet 2020;395:507-513.

2. Zou L, Ruan F, Huang M, et al. SARS-CoV-2 viral load in upper respiratory specimens of infected patients. N Engl J Med 2020;382:1177-11793.

3. Wang D, Hu B, Hu C, et al. Clinical characteristics of 138 hospitalized patients with 2019 novel coronavirus-infected pneumonia in Wuhan, China. JAMA 2020;323:1061-1069.

4. Holshue ML, DeBolt C, Lindquist S, et al. First case of 2019 novel coronavirus in the United States. N Engl J Med 2020;382:929-936.

\title{
Coronavirus disease 2019 (COVID-19) outbreak in Iran: Actions and problems
}

\author{
Milad Abdi ${ }^{1,2}$ \\ Student Research Committee, Faculty of Medicine, Iran University of Medical Sciences, Tehran, Iran and Department of Microbiology, Faculty of Medicine, Iran \\ University of Medical Sciences, Tehran, Iran
}

To the Editor-Coronaviruses (CoV) are a large family of viruses that cause illness ranging from the common cold to more severe diseases such as Middle East Respiratory Syndrome (MERS-CoV) and Severe Acute Respiratory Syndrome (SARS-CoV). Investigations have shown that SARS-CoV was transmitted from civet cats to humans and MERS-CoV from dromedary camels to humans. Coronaviruses are present in humans and many different species of animals, including camels, cattle, cats, and bats. Rarely, animal coronaviruses can infect people and then spread between people such as MERS-CoV, SARS-CoV, and the new virus named SARS-CoV-2., ${ }^{1,2}$

The SARS-CoV-2 coronavirus was first detected in China, and the disease it causes has been named "coronavirus disease 2019," which is abbreviated "COVID-19." Common signs of this infection include respiratory symptoms, fever, cough, shortness of breath, and breathing difficulties. In more severe cases, infection can cause pneumonia, severe acute respiratory syndrome, kidney failure, and even death. ${ }^{1,2}$

Coronavirus disease (COVID-19) was first reported from Wuhan, China, on December 31, 2019, and is now a concerning issue in the world especially in Iran, South Korea, and Italy.,3 In Iran, on February 19, 2020, two patients in Qom city were confirmed as SARS-CoV-2 positive. Afterward, the disease spread very rapidly in adjacent provinces near Qom, such as Tehran, Markazi, Isfahan, and Semnan provinces, and shortly thereafter in all 31 provinces of the country. By March 8,2020, according to Dr. Jahanpour, spokesman for the Ministry of Health and Medical Education, the total number of infected people who tested positive for SARS-Cov-2 had reached 6,566 and COVID-19 deaths had reached $194 .{ }^{4}$ Although these data continue to change, they show that the mortality rate has been $\sim 2.9 \%$ in

Author for correspondence: Milad Abdi, E-mail: miladabdi1369@gmail.com Cite this article: Abdi M. (2020). Coronavirus disease 2019 (COVID-19) outbreak in Iran: Actions and problems. Infection Control \& Hospital Epidemiology, 41: 754-755, https://doi.org/10.1017/ice.2020.86
COVID-19-positive cases. ${ }^{5}$ At the time of article submission, Iran ranked third in the number of people suffering from the disease after China and South Korea and second in the number of deaths and recovered cases. ${ }^{6,7}$

According to officials of the Iranian Ministry of Health and Medical Education (MHME), in the coming days the number of positive cases and deaths will increase. Thus, the issue of the COVID-19 outbreak and its control has become a top priority for the MHME. Iran formed the National Committee to Combat Corona and has decided to control this infection using all resources of the country, especially the knowledge, equipment, and skilled personnel. The MHME has initiated the following actions to combat the disease $e^{3,5,8,9}$ :

(1) Increased awareness and informed people about COVID-19 and recommended protective measures proposed by the World Health Organization (WHO) through media such as television, radio, etc, including the following recommendations:

- Wash your hands frequently and thoroughly with an alcoholbased hand rub or soap and water.

- Maintain at least $1 \mathrm{~m}$ (3 feet) distance from anyone who is coughing or sneezing.

- Avoid touching eyes, nose, or mouth with contaminated hands.

- Practice respiratory hygiene by covering mouth and nose with bent elbow, facial masks, or tissue when you cough or sneeze.

- Seek medical care early at the onset of fever, cough, and/or difficulty breathing.

(2) Restricted traffic in busy areas such as places of pilgrimage, tourism, and markets.

(3) Closed kindergartens, schools, and universities.

(4) Reduced office working hours.

(5) Cancelled the congregational prayer and Jumu'ah prayer (Friday prayer).

(C) 2020 by The Society for Healthcare Epidemiology of America. All rights reserved. This is an Open Access article, distributed under the terms of the Creative Commons Attribution licence (http://creativecommons.org/licenses/by/4.0/), which permits unrestricted re-use, distribution, and reproduction in any medium, provided the original work is properly cited. 